\title{
THE EUROCENTRIC, CHRISTIAN PATRIARCHAL STRUCTURAL SYSTEM APPROACH OF THE SOUTHERN AFRICAN CATHOLIC BISHOPS' CONFERENCE (SACBC): A CRITICAL ENGAGEMENT WITH THE BOOK GOD, LOVE, LIFE AND SEX
}

\author{
Itumeleng Daniel Mothoagae \\ Department of Biblical and Ancient Studies \\ University of South Africa
}

\begin{abstract}
In 2013 the Southern African Catholic Bishops' Conference released the book. "God, Love, Life and Sex: Guide and Resource for Christian Living Marriage and Family." In chapters five and six of this book assumptions are made on reasons why women choose to cohabit and have children outside of marriage. It further states that the African tradition and customs still need to be studied, thus objectifying and locating the African tradition within the categories of time, space and subjectivity. This categorisation of African tradition is an exercise of power and epistemic hierarchies within the colonial global normativity. In other words, they could not say anything on African tradition, precisely because, according to Canon Law, the Catholic Church does not recognise African traditional marriages as sacramental. For a Catholic and an African, such blanket statements made by the Catholic Bishops raise serious problems on the hermeneutical approach used by these bishops on the matter. It is the intention of this article to critically engage with the process of categorisation as an exercise of power. The socially constructed categories such as homosexuality, cohabitation, marriage and African tradition as outlined in the book God, Love, Life and Sex, indicate how patriarchy is a critical issue that negatively affects the lives not only of Black women, but of Black men as well. I will therefore argue that the approach of the Bishops is a Eurocentric, Christian Patriarchal Structural System of the West. Moreover, I maintain that these concepts are based on epistemic racism of the West, which continues to locate African tradition and worldview in the zone of non-being. The article will use two theories, Intersectionality and Decoloniality. Conclusions will be drawn as well as pointers for further research. This is not in line with the thinking of John Henry Newman who made the following assertion regarding the laity: "Really desire to know the opinions of the laity on subjects in which the laity are especially concerned.",
\end{abstract}

Key Words: Homosexuality; Cohabitation; Marriage; African Tradition; Eurocentric; Christian Patriarchal Structural System; Epistemic Racism

John Henry Newman, “On Consulting the Faithful in Matters of Doctrine”. July 1859.

http://www.fordham.edu/halsall/mod/newman-faithful.asp 


\section{Introduction}

The history of the book is extremely problematic, because it points to what Grosfoguel describes as follows: "Epistemic privilege and epistemic inferiority are two sides of the same coin. The coin is called epistemic racism/sexism."

In this article I will argue that what Grosfoguel is pointing out could be found throughout the book. As a result, epistemic privilege is seen in the categorisation of people and other sources of knowledge. Moreover, I will maintain that it is through such an approach that one can clearly identify the culture of clericalism found in the Catholic Church in South Africa today. The claim to have consulted the laity is a further indication of clericalism based on the notion that the priest acts in the person of Christ. For the sake of this paper I did not deal with the whole book but chose aspects of the book such as cohabitation, divorce, African traditional marriage and single parenting. I argue that the constant concern with pelvic issues makes the bishops lose sight of the very important things in the lives of the people of God. Thus, there is a clear need for a Kairos consciousness in the church so that the church, rather than measure the people in terms of how far they have kept the doctrine, can respond to the daily experiences of the people.

In my Master's thesis I argue the following with regard to Pauline churches: Meeks, according to Glancy, argues that 'the Pauline churches were especially attractive to persons of inconsistent status, including freed persons and women who controlled significant wealth'. 3

With this in mind one can speak without doubt of the contemporary church as having the same characteristics as the Pauline churches. Punt raises three critical issues regarding how body theology enabled Paul to formulate his moral teachings. Firstly, Paul later appropriated the images of the divine, by referring not to the God of Israel, but related also to Jesus Christ, thus adding at least two further aspects to the divine body. Secondly, an important aspect of the social location of Paul's life and theology was the increasing impact of the ideas and values of Hellenism. In other words, the body in terms of the ideas and values of Hellenism was generally viewed in a negative light. Thirdly, one cannot ignore the dominance of the patriarchal system in the first century CE. This is because, according to Punt, Christianity was shaped in a world characterised by patriarchy, whether Jewish or Hellenistic. Punt makes a very compelling observation when he links Pauline body theology as a moral theology, by arguing the following:

Since the first century, the body was perceived as belonging to some entity or power,' [t]he impact of redemption upon the body is for Paul above all else to transfer it from one form of slavery to another'. Ownership brings of course its own imperatives, with the owner's exerting and exacting morality is commensurate with the owner's expectations. ${ }^{4}$

It is within this context that I will maintain that failure to recognise the various aspects that contributed towards the formation of texts that we are reading today is an injustice to the laity and this constitutes clericalism at its best. It is therefore the task of theologians to challenge this custom by emulating people such as John Henry Newman who saw the laity as people who could contribute and help the church to respond in a constructive way to the issues that are affecting the people of God.

2 Ramón Grosfoguel, "The Structure of Knowledge in Westernized Universities Epistemic Racism/Sexism and the Four Genocides/Epistemicides of the Long 16th Century.” Journal of the Sociology of Self-Knowledge XI, Issue 1, 2013:74-75.

3 Itumeleng Daniel Mothoagae "New Testament as Normative: The Morality of Cohabitation with specific Reference to 1 Corinthians 7.” Master's dissertation, University of South Africa, 2013:19.

$4 \quad$ Ibid., 12-13. 


\section{Background and Outline of the Book}

According to the letter of the five archbishops in the book God, Love, Life and Sex, there was an inter-diocesan pastoral forum in 2000. It is worth noting that not all the bishops agreed with the stance and approach of the book. Its eventual publication in the name of the five archbishops appears to be a fudge to mask the dissension amongst the bishops themselves about the appropriateness of publishing the book. At this forum delegates from various dioceses chose marriage and family, faith formation of the laity and youth ministry as the most urgent pastoral priorities for the Catholic Church in Southern Africa. The letter further states that in 2008 marking the $40^{\text {th }}$ anniversary of the controversial encyclical letter of Pope Paul VI, Humanae Vitae a good number of Catholics ${ }^{5}$ asked the Bishops to speak out more clearly on the teaching of this important letter concerning marriage and responsible family planning. ${ }^{6}$ The letter specifically states that:

We, your bishops, have responded by publishing this book. It is based on the teachings of the Scriptures, Vatican Council II, the Catechism of the Catholic Church and several documents of the Popes and the Holy See. ${ }^{7}$

The archbishops in the letter refer to the fact that many Catholics are confused about many of the deep issues dealt with in the book. They maintain that part of this confusion has to do with the different views and arguments discussed in the contemporary world and that are increasingly influenced by Western culture. As a result they see it as imperative for them to take up these issues and try to explain what the Catholic Church teaches, and why the Church differs from Western culture on many issues. The Bishops refer to the Church as differing from Western culture, yet they do not actually say what they mean by the Church. Is it the African Church in Southern Africa or the whole Catholic Church? The letter also gives an outline of the book by stating that:

The first five chapters concentrate on marriage and married love. Much more attention is given to them in the hope that, in future, more attention will be given to the issues covered in chapters 6 to 12, and even to issues that we have not yet addressed in this book. ${ }^{8}$

It is within this context that one should locate the supposed reasons for such a book, with its peculiar title, as well as the politics within the Southern African Catholic Bishops Conference regarding the approach taken by the archbishops. Moreover, as I will show later there are serious claims made by the archbishops which raise questions on their hermeneutical approach, including the epistemic privilege and epistemic inferiority as a process of categorisation which is an exercise of power based on the notion of a Eurocentric, Christian Patriarchal Structural System as well as the challenges facing the Black Church.

\section{Emerging Problems}

In his critique of the book, Clohessy, points out twelve critical problems. I will briefly outline a few of these emerging problems. I will later attempt to engage further with some of these issues so as to illustrate the process of categorisation, epistemic privilege and inferiority, and a

\footnotetext{
5 The use of Italics in this text is to illustrate the hermeneutical approach as well as epistemic privilege and epistemic inferiority as a process of categorization which is an exercise of power based on the notion of a Eurocentric, Christian Patriarchal Structural System.

6 Southern African Catholic Bishops' Conference, God, Love, Life and Sex: Guide and Resource for Christian Living Marriage and Family. Pretoria, Gauteng: Southern African Catholic Bishops' Conference, 2013:v.

Ibid., v-vi.

$8 \quad$ Ibid., vii-viii.
} 
Eurocentric Christian Patriarchal Structural System. Firstly, Clohessy points to the structure of the book as inconsistent. Secondly, the book is prefaced with an imprecise introduction, which according to him raises more questions than it attempts to answer. Thirdly, the book begins with the study of marriage and suggests that the Holy Family of Nazareth is an ideal model of Christian family. Fourthly, regarding cohabitation and sex outside of marriage, it gives the following analysis: Southern African marriage and the family are in deep crisis for several reasons, such as social and economic, cultural and religious. Fifthly, on the issue of sexual assault and rape the book maintains that sexual abuse of children happens at all levels of society and is widespread especially in families. Sixthly, according to Clohessy, the chapter on same-sex issues is the weakest and the worst section in the whole book. It uses same-sex attraction, same-sex friendship and same-sex relationships almost interchangeably despite these being very different things. ${ }^{9}$

The issues outlined by Clohessy are important in this article as they point to methodological discrepancies that characterise a Eurocentric Christian patriarchal structural system. This is illustrated by the dichotomies such as: what the Catholic Church teaches, and why the Church differs from Western culture on many issues, the Church and traditional African marriages, marriage and cohabitation, same-sex attraction, same-sex friendship and same-sex relationships. It is evident from the above-mentioned notions, particularly on what the Catholic Church teaches, and why the Church differs from Western culture, that the Church in South Africa is not the product of what Grosfoguel refers to as a capitalist/ patriarchal/ westerncentric/ Christian-centric/modern/colonial/world-system. ${ }^{10}$

The very term 'Western culture,' moreover, seems to denote that there is one Western culture, static and not dynamic, universalistic and not pluralistic. Such an assertion by the bishops indicates an exercise of power through the process of categorization and epistemic privilege. In other words, their reason why there are these problems is because of Western culture. Yet at the same time, the book does not define Western culture, nor does it spell out the essential differences from other cultures.

Another dichotomy is the Church and traditional African marriages. Here one sees very clearly the process of categorisation and epistemic privilege, on which I will expand in the next section. In Chapter Six 6.4 of the book the Bishops make the following assertion:

In civil and African traditional marriages there is a commitment by the couple to stay together and there is a sense of security for the future. For Catholics, however, both these forms of marital union are not sacramental marriages until they invite Christ into their lives through the Sacrament of Matrimony. ${ }^{11}$

The above citation points to the categorisation of civil and African traditional marriages as inferior epistemologies. This inferior categorisation is what Grosfoguel and Maldonado-Torres identify as the zone of non-being, where Catholic marriage falls within the zone of being. ${ }^{12}$ In other words, anything that falls within the zone of non-being cannot be intelligible and it therefore should rely on the representation of the zone of being. This, according to Crenshaw, is a representational intersectionality failure to acknowledge the significance of the other, and the power relations that each attempts to challenge are strengthened. ${ }^{13}$ Such an approach sees

\footnotetext{
Christopher P Clohessy, A response to the Bishops' Book on God, Love, Life and Sex. Cape Town, 2013:1-5. Ramon Grosfoguel, "Racism”, Intersectionality and Migration Studies. Decoloniality Summer School, $2014: 2$. Southern African Catholic Bishops' Conference, God, Love, Life and Sex: Guide and Resource for Christian Living Marriage and Family. Pretoria, Gauteng: Southern African Catholic Bishops' Conference, 2013:88. 
no value in the African spiritualities and rituals as expressions of a pluralist manifestation of God's active role in salvation history.

\section{The Structural Location of African Tradition in the Zone of Non-being}

The failure of the Bishops to recognise the legitimacy of African traditional marriages as expressed in the sacrament of marriage symbols and rituals raises serious concerns. Yet, at the same time, it points to the fact that the Catholic Church in South Africa still seems to be a foreign Church. The question could be: what roles do Post-Synodal documents such as Ecclesia in Africa and the Synod of African bishops play in sustaining the stance of the bishops? It is precisely in these synods of Africa that the model of the Church in Africa identifies and acknowledges as 'Family'. The pertinent question is what African values of family did the bishops espouse in these Synods - and yet, the book in taking the Eurocentric approach contradicts Synod and post-Synodal promulgations. In their book the bishops maintain that:

In the case of traditional African marriage, we as Church need a deeper study and a better understanding of the whole process leading up to marriage and including the early years of marriage. $^{14}$

The above-mentioned citation points to the view that African traditional marriage or anything African is primitive and has nothing to offer. As a result, knowledge is universalised and is measured in relation to what Grosfoguel refers to as epistemic racism in the following manner:

The knowledge produced from the social/historical experiences and world views of the Global South, also known as 'non-Western,' are considered inferior and not part of the canon of thought. ${ }^{15}$

From this thinking it would seem that the bishops see it as proper for them to measure and categorise African traditional marriage practice as not sacramental marriages until they invite Christ into their lives through the Sacrament of Matrimony. ${ }^{16}$ Such an approach is an indication of a lack of understanding of social justice, particularly concerning its clientele (the laity). One can further add that such an approach is a pre-Vatican II conceptual way of thinking. The latter laid emphasis on culture as a prepaeratio evangelicae - a preparation for evangelisation - and gave impetus to the process of inculturation. I would like to submit that such an approach illustrates a worldview of the nineteenth century missionaries and of the colonisers of Africa who saw the continent as a barren land waiting to be penetrated and fertilised with the gospel. This is expressed, for example, in the attitude of Moffat regarding the whole of Batswana - and it would seem the whole of Southern Africa - as ignorant and godless. For Moffat, the Black people are ignorant and godless, and yet there is hope for them under the hand of a gardener-farmer to cultivate their parched souls into the fertile fields of salvation. Moffat states precisely that:

Satan is obviously the author of the polytheism of other nations; he has employed his agency with fatal success in erasing every vestige of religious impression from the mind of Bechuan, Hottentots and Bushmen, leaving them without a single link to unite them to the skies. Thus the missionary could not make appeal to legends, or altars, or to an unknown

14 Southern African Catholic Bishops' Conference, God, Love, Life and Sex: Guide and Resource for Christian Living Marriage and Family. Pretoria, Gauteng: Southern African Catholic Bishops' Conference, 2013:88.

15 Ramon Grosfoguel, "The Structure of Knowledge in Westernized Universities Epistemic Racism/Sexism and the Four Genocides/Epistemicides of the Long 16th Century." Human Architecture: Journal of the Sociology of SelfKnowledge, 2013:75.

16 Italic is inserted to emphasis categorisation and epistemic racism underlining the statement of the bishops in the quotation. 
God or to ideas kindred to those he wished to import... Their religious systems are like those streams in the wilderness, which lose themselves in the sand and entirely disappear. It devolves on the missionary to prepare for the gracious distribution of the waters of salvation in that desert soil, sowing the seed of the word, breathing many prayers, and shedding many a tear, till the Spirit of God should cause it to vegetate, and yield fruits of righteousness. ${ }^{17}$

This is the complete opposite of the document Ecclesia in Africa. Paragraph 43 of the document asserts the following regarding African culture and tradition:

In African culture and tradition the role of the family is everywhere held to be fundamental. Open to this sense of the family, of love and respect for life, the African loves children, who are joyfully welcomed as gifts of God. "The sons and daughters of Africa love life. It is precisely this love for life that leads them to give such great importance to the veneration of their ancestors". 18

The citation above to some extent contradicts the position of the bishops in the sense that the document Ecclesia in Africa suggests that the Church has some knowledge of African tradition as well as its contribution, particularly on the family and other aspects of spirituality. It is for this reason that I am inclined to believe that the Catholic Church in South Africa has always been a South African Church expressing in its worship and symbols African spirituality. Moreover, how can the Church serve people that it does not understand? These and many more questions are imperative in contextualising the attitude of the bishops towards cohabitation, HIV \& AIDS, single parenting, homosexuality, bisexuality, trans-sexuality, contraception, traditional marriage as authentic and acceptable to Christianity, and divorce.

This is in complete opposition to one of the statements of Pope Francis on the issue of the need for the Church to have better bishops. He asserted that:

The Church does not need apologists for their own agendas or crusaders for their own battles, but humble and faithful sowers of the truth. ${ }^{19}$

I would like to submit that another dimension that the Pope offers is the notion of being dirty as a bishop; in other words, living with those who are in the margins, stigmatised, and ridiculed by society, rather than using a measuring stick to determine the extent of their sin; or not being in line with the doctrine of the Church. In his address to some newly-appointed bishops Pope Francis said the following:

The second thought the Holy Father explained was to 'walk with the flock' or rather 'walking alongside the faithful and all those who turn to you, sharing joys and hopes, difficulties and sufferings'. ${ }^{20}$

The only thing that matters or that seems to matter with the authors of this book is a capitalist/ patriarchal/Western-centric/Christian-centric/modern/colonial/world-system which contains within itself absolute knowledge in determining what makes a 'religion' a 'religion' - with all its symbols and rituals an authentic religion. It follows then, that, there is a clear location of African spirituality by the Catholic bishops in South African within the zone of non-being. ${ }^{21}$ The assertion by the Catholic Church's leadership that African traditional marriage still needs

\footnotetext{
17 Robert Moffat, Missionary Labours and Scenes in Southern Africa. London: J Snow, 1842:244.

18 John Paul II "Ecclesia in Africa: Post-Synodal Apostolic Exhortation.” 1995:16.

19 David Gibson, "Pope Francis: The Church needs better Bishops; go find them." Religion News Service, Feb 27 2014.

20 Ibid.

21 African spirituality is used here as the totality of African tradition. To isolate one aspect of African spirituality namely marriage, is decadent. Since African tradition is not universalistic as the church is, hence it does not claim epistemic privilege nor does it use the process of categorisation as an exercise of power.
} 
to be studied, as I have argued previously, is a model that was used by the missionaries. Yet at the same time there is a claim that the Church needs to be Africanised. What do they mean by Africanisation of the Church whilst those who are supposed to pioneer this, are more Western than the Western church itself?

Such an attitude is contrary to the statements made by Pope Francis regarding the role of a bishop or the clergy. Addressing the Congregation for Bishops, Pope Francis remarked: To choose such ministers we all need to raise our sights, to move to a higher level. ${ }^{22}$

This points to the fact that there is a greater need to move from clericalism to servant leadership. This type of attitude is clearly missing in the book under review. It is for this reason that the assumption is that we have the answers and we know what is good for you though we are not living the type of life you are living. In other words, we know it better than you because we were ordained so that we could shepherd you and 'lead' you to Christ. Such a view is challenged by Pope Francis when he asserts that:

Bishops should be guardians of doctrine, not to measure how far the world lives from the truth it contains, but to fascinate the world, to enchant the world with beauty of love, to seduce it with the free gift of the Gospel. ${ }^{23}$

The statement by the Pope is the complete opposite of the approach of the bishop-writers of this book. This is because in their view they measure how far the people of the local church live from the truth 'the church' contains. As a result they do not fascinate, nor enchant the local church with the beauty of love by loving those in cohabiting relationships, living with HIV \& AIDS, divorced and homosexuals. Moreover, one can say there is no listening to the Catholic laity. This view is asserted by Newman in his letter On consulting the faithful in matters of Doctrine (July 1859).

In his letter Newman argues that Catholic Bishops should listen to the Catholic laity. He further insists that:

The laity have abilities in their own sphere, to insist, essentially, that the consensus of the faithful may preserve important doctrines even when the bishops fail. ${ }^{24}$

I fail to see in the claims of the bishops that they have consulted the laity in the content of the book based on the arguments presented in the previous section by Clohessy. This is because had they done so, they would have known that issues such as divorce, HIV \& AIDS, contraception, homosexuality, cohabitation and African traditional marriage are complex and that there is no clear right or wrong answer. Amongst the black communities there is still the widespread practice of African traditional marriages. In other words the practice of lobola or bogadi is still part of the community's culture and tradition. For that reason it still earns to be respected and acknowledged as part of the daily lives of Black Church practice.

In an article I published (2013) I argued as follows:

When one deliberates on the unwarranted amount of time and energy the church has devoted to what Chris Marshall calls "Pelvic issues, sexuality, reproduction, and abortion - which receive nothing like the same degree of attention in scripture". ${ }^{25}$

22 David Gibson, "Pope Francis: The Church needs better bishops; go find them." Religion News Service, Feb 27 2014.

23 See footnote 22.

24 John Henry Newman, “On Consulting the Faithful in Matters of Doctrine.” July 1859. http://www.fordham.edu/halsall/mod/newman-faithful.asp

25 Itumeleng Daniel Mothoagae, "Expelled and Peripheral: The Resistance of the Black Marginalised Majority and the Call for a New Liberation in Post-Apartheid South Africa." Scriptura 112, 2013:1:8. 
It is evident from the citation that the Catholic Church's leadership in South Africa is busily concerned with pelvic issues rather than socio-political and economic conditions to which their followers are subjected. It is for this reason that the capitalist/patriarchal/Western-centric/ Christian-centric/modern/colonial/world-system is used as a model and supposedly an answer to the issues that are affecting the Black Church. ${ }^{26}$ Such an approach then suggests that the zone of being contains all what it is to be human, while the zone of non-being contains all what is not human. This notion privileges the zone of being (Catholic Church) over the other groups (African tradition) by inferiorising the latter.

I would like to deal with the categorisation of the following: cohabitation, single parenting, African traditional marriage and rape. I will argue that the categorisation of these issues contributes to the disempowerment of those who are affected by them. The book fails to see how these issues intersect with each. It sees no link between these issues and race, geopolitical, economic, social, structural, and institutional factors, precisely because the Church in South Africa is still a colonial product. The colonial aspect of it is to claim to be providing a guide and resource for Christian living, a concept located in the zone of being the 'I' and 'Other'. It uses a capitalist/patriarchal/Western-centric/Christiancentric/modern/colonial/worldsystem as a measurement of categorising where and how these issues are to be addressed.

Thus, by the use of Eurocentric, a Christian Patriarchal Structural System method it does not take into account the events that take place at the zone of being and non-being. Precisely because as Grosfoguel puts it:

The 'I' in the imperialist/capitalist/patriarchal global system is western, heterosexual, masculine, metropolitan elites and/or westernized, heterosexual, masculine elites in the peripheries of the world-system. ${ }^{27}$

This problematises the attitude and approach used by the five Bishops in attempting to provide what they call 'guide and resource for Christian living'. In their 'guide' the Catholic Church in South Africa fails to recognise and differentiate intersectionalities - or rather entanglements between the zones of being and non-being. ${ }^{28}$ This illustrates the world system that the five Bishops are operating from, which is the imperialist, capitalist and patriarchal system. Thus, according to Grosfoguel, class, gender, and sexual oppression lived within the zone of being and non-being and are not the same. What this means, according to Grosfoguel, is that in the South African context there has always been the privileged and the unprivileged, superior and inferior, oppressed and free, external and internal racial/colonial subjects. These markers make it difficult to want to address the issues, particularly because of how they are stratified.

In other words, using the same principle of gender and sexual oppression in Grosfoguel and Crenshaw, Western women and gays/lesbians disproportionately enjoy greater access to resources, wealth and power than the oppressed non-Westernised women or gays/lesbians in the zone of non-being.

26 I use Black church here to intentionally draw attention to the notions of race, geo-political, economic, social, structural, institutional location of the black church. At the same time black church denotes the space that it occupies in the broader church (Catholic Church). Black church further implies the 'incorporation' of African tradition (spirituality) within the Church. In South Africa the Catholic Church has contributed much in terms of the fight against apartheid. It is also important that there has always been the white, Indian, coloured and black church. It is for this reason that priesthood training was separate until the Bishops decided, as a stand against apartheid, to amalgamate the two institutions - one for the whites and one for the Blacks.

27 Ramon Grosfoguel, "Racism”, Intersectionality and Migration Studies.” Decoloniality Summer School notes, 2014:6.

28 Grosfoguel uses this concept from Fanon's book Black Skin White Mask. See footnote 27. 


\section{Clericalism a Barrier to responding Pastorally to the Changing Times of Society}

In his article Prior (2013) argues that for the past 50 years there has been a number of the laity in the Catholic Church that have taken on leadership positions in their various parishes. He maintains the following regarding the involvement of the laity:

This is seen as a response to the teaching of Vatican II (1962-1965) which proclaimed that all Christians are equal through their baptism. ${ }^{29}$

According to Prior, this is a reversal of centuries of clerical power on the one hand and passivity of the laity on the other hand. He asserts that there is a strong movement from the Catholic Church's centralised authority to reverse this recent progress. One could say, then, that the stance of the bishops regarding 'pelvic issues' is an illustration of these developments. Moreover their lack of responding to these issues pastorally with care and sensitivity is also an expression of wanting to centralise and authenticate the present clerical culture in the church and at the same time deny the baptised equality as well as the teaching of Vatican II. Clericalism is located within the functionality of the clergy according to Prior's definition. As a result, he argues that clericalism seeks to draw the distinction between the laity and the ordained on the basis of the theology of the priesthood, which emphasises that a priest acts in the name of Christ (in persona Christi capitas) as well as the hierarchical structure of the church. It is such a theology that centralises clergy, particularly the magisterium, as people who can and should teach, guide and refute on matters of faith and morals. According to Canon Law paragraph number 752 says the following:

While the assent of faith is not required, a religious submission of intellect and will is to be given to any doctrine which either the Supreme Pontiff or the College of Bishops, exercising their authentic magisterium, declare upon a matter of faith and morals, even though they do not intend to proclaim that doctrine by definitive act. Christ's faithful are therefore to ensure that they avoid whatever does not accord with that doctrine. ${ }^{30}$

Thisprovides one of the examples of clericalism in the church. Moreover, the laity is to adhere to the teachings of the Magisterium. The implication of that is that as intelligent people the laity is not to ask questions but rather see to it that they avoid whatever does not accord with that doctrine. This contrasts to the concept of sensus fidelium ${ }^{31}$ as espoused by Newman. Prior maintains that:

In an 1854 letter he (Newman) ${ }^{32}$ explained that he had wished to know the sentiments of the people as well as those of the clergy. If the Pope thus consults the laity regarding a matter of dogma, how much more should lay people not be consulted in matters which affect them and their daily lives? ? $^{33}$

It is without doubt that the intention of the bishops was not what Newman had in mind. This is seen clearly in the way the content of the book does not reflect the existential experiences of the faithful. Rather, it reflects their own experiences separate from the sheep,

29 Laurence Prior, "The Development of Clericalism and the Need for a Theology of Secularity". In Tradition: Fixed and Mobile: Essays in Honour of Rev Prof Rodney Moss. (Ed.) Itumeleng D Mothoagae \& Laurence Prior.

Pretoria: Research Institute for Theology and Religion, 2013.

Canon Law Society Trust. The Code of Canon Law. London: HarperCollins, 1997:175.

31 Newman gives an example of the Pius IX and maintains that the hierarchy should seek to know what the belief of the people is. This according to him is their witness to apostolic tradition. This is seen in the statement of the Pope when he was proclaiming the dogma of the Immaculate Conception, by asserting that he already knew the sentiments of the bishops, still he had wished to know the sentiments of the people also concerning this teaching, argues Prior (see footnote 29, 37).

32 Author's own insertion.

33 See footnote 29,36 . 
meaning the people of God. One can say that they lacked in their approach what Swart (2013) refers to as Kairos consciousness. Swart makes the assertion that:

My point of departure in this article is one that duly wants to acknowledge what appears to be visible signs of a reviving kairos consciousness in the present-day post-apartheid socioreligious landscape. At the same time, however, this acknowledgement also leads me to go one step further by observing how this new development appeals strongly to my own interest in researching the nexus between religious change and social change in post-apartheid South African society. This research focus is as much concerned with how religion and religious traditions manifest themselves as dynamic, changing phenomena over time as with how religion and religious traditions also hold the potential to act as catalysts of social change (both negatively and positively) in broader society. ${ }^{34}$

It is for this reason that I argue that failure to reflect on the existential experiences of the people blinds the bishops to responding to the post-apartheid socio-religious landscape. This in a way renders them irrelevant to the people, precisely, because their point of departure is that of teach, guide and refute, rather than that of Newman's sensus fidelium and consensus. Prior concludes the following regarding Newman's exhortation to the bishops:

Newman's concluding exhortation to the bishops could also be seen as a warning and, perhaps also, a description of what happened historically, as we can see in many countries today. Where the laity have remained passive, and even uncommitted to the church, they become 're-connected' only for occasions of infant baptism, First Communion and perhaps burial. When well-read lay persons are not listened to they either 'back off' because their potential contribution is not recognised, or they leave the institution altogether. ${ }^{35}$

What Prior is pointing to is the extent to which clericalism could become a barrier. I would like to draw attention to the fact that the bishops maintain that they involved the laity and asked the laity for inputs. Yet, the views of the laity were overlooked precisely because of the clerical culture that is found in the church. One couple responded to the draft manuscript in the following manner:

We take up a few specific examples of blatantly untrue positions in the booklet.

- There is an assertion that those who practice natural family planning have far fewer divorces than those who use contraceptives. This is unadulterated twaddle, worthy of the most devious of politicians. It is a blatantly incoherent argument, and the writer(s) know it. There is no evidence whatsoever that contraception causes divorce, as insinuated by this false correlation. Both the lower divorce rate and the use of natural family planning methods are characteristics of people who are strongly loyal to the church.

- Natural family planning is touted as being natural, and therefore good. By implication, contraceptives are bad because they are unnatural. This begs the question: "Where does natural start and end?" What parts of technology are unnatural and therefore bad? Is it bad to use artificial sweeteners to reduce weight rather than to abstain from sugar? Are genetically modified seeds unnatural and therefore bad, despite the green revolution they have wrought? The argument from 'natural law', endorsed by Humanae Vitae, has no persuasive force whatsoever. The hierarchy applies it only to human sexuality but nowhere else. And in doing so, the differing parties are arbitrarily and vaguely classified as "open to human life" or not. But you can be completely closed to human life and

34 Ignatius Swart, Revival of a Kairos Consciousness: Prolegomena to a Research Focus on Religious and Social Change in Post-apartheid South Africa. Studia Historiae Ecclesiae, 2013:86.

35 See footnote $29,39$. 
practice natural family planning. And you can be open to new life, and use contraceptives. To suggest otherwise is an insult to those who use contraceptives in good conscience to plan their families in a socially responsible fashion. In point of fact, the bishops have no business injecting their abstract notions of morality into the bedrooms of married couples.

- The recommendation that married couples in an AIDS context should abstain from sex rather than use condoms seems premised on an abhorrence of condoms. Their data cited from Trajillo and Clowes is not from a peer-reviewed medical source, but from an openly pro-life (actually just anti-condom) forum. It will fool and scare the ignorant, but it won't make an impact on those informed about research methodology. It is akin to voodoo science.

It is also in conflict with the views of a fellow bishop. The following is taken from The Tablet (that awful liberal Catholic magazine): "The Catholic Church should update its teaching on the use of condoms to prevent the spread of HIV, and allow them to be used in certain cases," the Bishop of Sankt Pölten, Klaus Küng, said. Küng, who is a former vicar-general of Opus Dei and a qualified gynaecologist, argued in a long article in the German conservative, Tagespost, that in the case of married couples where one partner is infected, for example, condoms "could be allowed or indeed prescribed in order to protect the partner who was not infected."

- The grandstanding of the hierarchy in trying to differentiate between divorce and annulment is deeply suspect. As a matter of fact, it seems entirely plausible to make a case for annulling just about any marriage. The condition for a valid marriage: "Not committed to remaining married for life" is an escape hatch that can almost always be invoked, and probably almost always applies. How do you credibly prove such a claim - one way or the other? How do you ascertain that each individual had whole-heartedly committed to a life-long relationship when there would be a hesitancy and angst in the soul of every thinking person. Existentially, in such moments, most of us just take a plunge and hope for the best - just as young men do when they decide to become priests. There is almost always doubt and uncertainty. It seems as if the hierarchy is thinking and regulating in terms of abstract categories that do not correspond to daily existential experience.

- The audacity of wanting to publish the following kind of bigotry in the name of the Catholic Church is breathtaking:

"It is God's plan that love-giving and life-giving belong together in the marital act. In other words, sex and children belong together. The breaking of this link through contraception has opened wide the door to all kinds of sexual immorality and perversions with disastrous consequences, such as infidelity in marriage, premarital sex, extra-marital sex, abortion, test-tube babies, homosexuality and paedophilia."

The non sequiturs in this passage abound. Contraception within marriage no more opens up a gap between sex and children than does natural family methods. Furthermore, there is no scientific correlation between contraception and the list of 'perversions'. It is bizarre and insulting to include homosexuality in a list of 'perversions' alongside paedophilia, since one involves consenting adults, whereas the other involves adult abuse of innocents.

Rather being attributable to contraception, it is widely accepted that both these proclivities are not a matter of will and are not reversible. Even the Catechism of the Catholic Church acknowledges that. Besides, apart from the modern phenomenon of 
test-tube babies, the listed 'perversions' have been around since the dawn of time. You rightly protest when an attempt is made to link celibacy and paedophilia. Your inferences and innuendos above are equally perverse and bigoted. ${ }^{36}$

The above citation clearly points to the challenges that the church faces and the ignorance of the leadership to address these issues. Moreover, it indicates without doubt that clericalism ${ }^{37}$ is at the centre, precisely because by its very nature clericalism assumes knowledge, hierarchy and separates the 'sheep' from the 'goats', 'grace' from 'defiled', 'anointed' and 'chosen' from 'secular'. I would like to submit that the basis for clericalism in the church, as I have pointed out, is the separation between the laity and the clergy based on functionality and the notion that a priest is in persona Christi. The latter is regarded as part of tradition. In his article (2013) Moss reflects on tradition as fixed and mobile, and maintains the following:

In the next two senses, 'dramatic development' and 'incipient development', Thiel accounts for the more radical mutations in tradition from the apostolic church to the contemporary church. 'Dramatic Development' is a sense of tradition which refers to the process by which an aspect of belief passes beyond the first or second sense and either falls away or changes significantly. ${ }^{38}$

Thiel, as cited by Moss, further maintains that:

This sense judges a particular belief, doctrine or practice is developing in such a way that its current authority as the authentic teaching of the Magisterium, and thus its status as either the literal sense or the sense of development-in-continuity, will be lost at some later moment in the life of the Church and that such a teaching or practice exhibits signs in the present moment that this final loss of authority has begun to take place. ${ }^{39}$

The argument presented above points to the past examples on the church's teaching regarding usury, slavery, religious freedom, as well as the exclusion of separated churches from membership in one, true Church. As a result one can therefore deduce that the teachings on birth control, as well as priesthood are current examples of dramatic developments, argues Moss. ${ }^{40} \mathrm{I}$ wish to maintain further that even teachings on African traditional marriages, homosexuality, single parenting, divorce and cohabitation are some of the current examples of dramatic developments and therefore they are bound to change.

According to Thiel, as cited in Moss, the following are three criteria for dramatic development:

Magisterial teaching judged not to have been widely accepted by the faithful, teaching that presents rational justification for its position through theological argument and which does not enjoy support from a wide segment of Catholic theologians. ${ }^{41}$

Based on the above-mentioned argument Moss maintains that one can therefore conclude that in theory dramatic development could occur among non-infallible doctrine on the one hand. On

\footnotetext{
36 A response to the draft manuscript of the book Lay Couples Personal Perspectives on "A Guide for Christian Living." July 2010.

37 I follow Prior's definition of clericalism in the following manner: lay people are merely 'participating in the apostolate of the hierarchy' or' helpers of Father', who can withdraw their services when he feels they are not needed (see footnote 29:29).

38 Rodney Moss, "The Living Tradition of the Church: Fixed and Mobile.” In Tradition: Fixed and Mobile: Essays in Honour of Rev Prof Rodney Moss. (Ed.) Itumeleng D Mothoagae and Laurence Prior. Pretoria: Research Institute for Theology and Religion, 2013:21.

Ibid., 38.
} 
the other hand Thiel maintains that because there is lack of explicit definition of infallible teaching, it therefore makes it difficult to know what doctrines are infallible and which are not. ${ }^{42}$ It is for this reason that I argue in the next section that these form part of the challenges facing the black church in South Africa. Yet at the same time the book argues that it is responding to these challenges which to them (leadership) are pelvic challenges, while there are socio-political, economic challenges with which the majority of the churches membership are struggling.

\section{The Challenges Facing the Black Church in South Africa}

The Catholic Church in South Africa faces many challenges. The book (2013) points out these challenges, but omits pointing out clericalism. For example:

We, your bishops, have responded by publishing this Book. It is based on the teachings of the Scriptures, Vatican Council II, the Catechism of the Catholic Church and several documents of the Popes and the Holy See. It presents the teaching of the Catholic Church on marriage and family, as well as on other important issues concerning life, relationships and human sexuality. ${ }^{43}$

Moreover, the back cover of the book suggests that the book has all the answers to contemporary moral issues. One of the bishops asserts:

During the Synod of Bishops in October and again during the Conference of the Pontifical Council for Catholic Healthcare, I kept saying to myself: We really must get our Book out soon; it has so many of the answers. ${ }^{44}$

What one can draw from the above-mentioned quotations is that the clerics of the Church claim to have solutions for contemporary society. Moreover, this is a medieval tendency of thinking that the leadership of the church could have 'answers; for society'. Another indication of clericalism in the approach of the bishops is found in the fact that although they consulted a number of lay professionals, including some who are not mentioned in the book, there have been some reservations on the part of many of the laity concerning the content of the book. The response of the bishops was to ignore the advice from those they consulted - they opted to continue with the book's publication without heeding the call not to publish it as it is.

In my Master's dissertation (2013) I argue the following regarding the issue of cohabitation, namely, that according to Mokomane within the traditional Tswana system for social organisation, there is no place for unions in which couples cohabit without the approval of their respective families. ${ }^{45}$ For the church leadership to be unable to recognise the role of tradition within the lives of its people is a denial of the relevance and existence of such traditions. Moreover, this indicates failure to recognise that in South Africa there are two systems that claim authority over an individual amongst black South Africans, namely, the church in a broad sense and African tradition. These two systems do not complement one another. As a result, the Catholic Church uses clericalism as a measure - or rather the doctrine of the Church, which is a Eurocentric, Christian Patriarchal Structural System of the West, to argue against other traditions. Such an approach by the Bishops compels one to question their pastoral response on matters of cohabitation, homosexuality, single parenting and divorce.

42 Ibid., 22.

43 Southern African Catholic Bishops' Conference, God, Love, Life and Sex: Guide and Resource for Christian Living Marriage and Family. Pretoria, Gauteng: Southern African Catholic Bishops' Conference, $2013: v$, vi. Ibid., refer to the back cover of the page.

45 Itumeleng Daniel Mothoagae, "New Testament as Normative: The Morality of Cohabitation with Specific Reference to 1 Corinthians 7.” Master's diss., University of South Africa, 2013:4. 


\section{The Use of Biblical Texts in the Book}

Throughout the book the bishops use biblical texts to argue that issues such as divorce, contraception, homosexuality, premarital sex, and so on, are against the teaching of Christ. Yet one thing that they miss is that each biblical text, be it Hebrew or Christian, has its own context. Moreover, one cannot use the biblical texts as a norm. In chapter five, the bishops argue the following regarding divorce:

In the Old Testament the Prophet Malachi condemns divorce: "for I hate divorce, says the Lord, God of Israel" (Mal. 2, 16). Jesus, in the Sermon on the Mount, gives his very clear teaching rejecting divorce: "It was also said, whoever divorces his wife must give her a bill of divorce. But I say to you, whoever divorces his wife (unless the marriage is unlawful) causes her to commit adultery and whoever marries a divorced woman commits adultery" (Mt. 5, 31-32; see also Mt. 19:3-9). ${ }^{46}$

Undoubtedly the texts cited above have their own context. They were meant to respond to the social conditions of the recipients, thus could they be normative to contemporary society? It is for this reason that in my Master's dissertation I maintain that:

First century marriage practices in the Graeco-Roman world and in early Christianity were diverse. This is because each region had its own practices. ${ }^{47}$

These citations point to the diversity within the Graeco-Roman world. As a result what we find is that there were various marriage practices which can be found on Jewish, Greek and Aramaic marriage and divorce papyri, as well as on the Graeco-Roman marriage and divorce papyri. It is within these papyri that one comes to an insight into the type of approach the ancient people had towards marriage and divorce. Moreover they point without doubt to the fact that the "one size fits all" type of marriage practices did not work in ancient times. Yet this seems to be the approach and practice of the "Church since missionaries came to this continent". Yet, even though Christianity has been in South Africa since the arrival of the Dutch and subsequently filtered through to the African people through the work of the missionaries, they all seem to see anything African as primitive, heathen and savage. Another aspect that the bishops are overlooking in their blind quoting of biblical texts is the fact that, as I argue in my thesis:

In her investigation [of], premarital cohabitation in ancient Judea: the evidence [derives from] the babatha archive and the Mishnah. Tal Ilan raises the following question as to whether a man and a woman could or would cohabit before they were officially married. She limits herself to the matrimonial practice in second century CE Judea by studying a marriage contract that was discovered in the Judean desert. In this contract, there is a clause that mentions that a couple had lived together before marriage. ${ }^{48}$

The abovecitation actually puts into question the very attempt by the bishops, who seem to condemn everything that is deemed to be outside 'orthodoxy' as if anything else is nonauthentic or 'unorthodox'. It is without doubt that such an approach by the bishops is first and foremost a categorisation of God's people as well as an exercise of power. The result of this type of approach attempts to construct people's identity based on divorced or married, single or cohabiting, homosexual or heterosexual - rather than looking at people as people, as the redeemed. It is through categorisation that they fail to see the incarnation of Christ as an ongoing event rather than something that happened once in time and space.

\footnotetext{
46 Itumeleng Daniel Mothoagae "New Testament as Normative: The Morality of Cohabitation with Specific Reference to 1 Corinthians 7." Master's diss., University of South Africa, 2013:75.

47 Ibid., 83

48 Ibid., 89.
} 


\section{Conclusion}

In this article I attempted to engage critically the book, God, Love, Life and Sex. I have argued that first and foremost the church's leadership has failed to listen to the people, because as far as they are concerned they know what the people need. Yet they miss the basic foundation of Christianity which is the incarnation. Such failure to recognise the incarnate God in every person has led them to believe that theirs is to safeguard the teaching of the church rather than the salvation of souls. Hence they used the doctrine of the church to measure how far the people of God have violated and disregarded the doctrine, without focusing on their faith. I have shown that the use of epistemic privilege is present throughout the book as if other sources of knowledge such as the Africa traditional marriages cannot offer a deeper understanding of the concept of marriage within the African tradition.

The continual categorisation of people into divorced, remarried, cohabiting, homosexual, heterosexual point to the church's obsession with pelvic issues rather than how the church can effectively respond to the social, religious, political and economic situation that the majority of the people are experiencing. This is in many ways a further indication that the church's leadership is not aware of these issues and as a result they seem to lack the Kairos consciousness, of which the church needs to be at the forefront. The continual use of biblical texts without taking into cognisance the context in which the text is written is problematic. It is therefore the task of theologians in South Africa to develop the type of approach used by John Henry Newman, who advocated for the voice of the laity to be heard. Such an approach will further reform the church and thus challenge the cancer of clericalism that seems to be eating up the church. This will lead to the decoloniality of power and identity construction that is determined by which category one belongs.

\section{BIBLIOGRAPHY}

A response to the draft manuscript of the book "Lay Couples Personal Perspectives on 'A Guide for Christian Living." July 2010.

Canon Law Society Trust 1997. The Code of Canon Law. London: HarperCollins.

Clohessy, CP 2013. “A Response to the Bishops' Book on God, Love, Life and Sex.” Cape

Town: Southern Cross Catholic News Paper.

Crenshaw, K 1991. "Mapping the Margins: Intersectionality, Identity Politics, and Violence against Women of Color." Stanford Law Review, Vol. 43, No. 6, 1991:1241-1299.

Gibson, D 2014. "Pope Francis: The Church needs better bishops; go find them." Religion News Service, Feb 27.

Grosfoguel, R 2014. "Racism", Intersectionality and Migration Studies. Decoloniality Summer School notes.

Grosfoguel, R 2013. "The Structure of Knowledge in Westernised Universities Epistemic Racism/Sexism and the Four Genocides/Epistemicides of the Long 16th Century." Journal of the Sociology of Self-Knowledge XI, Issue 1:74-75.

John Paul II 1995. "Ecclesia in Africa: Post-Synodal Apostolic Exhortation." Vatican: Libreria Editrice Vaticana.

Moffat, R 1842. Missionary Labours and Scenes in Southern Africa. London: J Snow. Mothoagae, ID 2013. New Testament as Normative: The Morality of Cohabitation with Specific Reference to 1 Corinthians 7. Unpublished Master's dissertation. Pretoria: University of South Africa. 
Mothoagae, ID 2013. "Expelled and Peripheral: The Resistance of the Black Marginalised Majority and the Call for a New Liberation in Post-Apartheid South Africa." Scriptura 112:1:8.

Moss, R 2013. The Living Tradition of the Church: Fixed and Mobile. In Tradition: Fixed and Mobile: Essays in Honour of Rev Prof Rodney Moss. (Ed.) Itumeleng D Mothoagae \& Laurence Prior. Pretoria: Research Institute for Theology and Religion.

Newman, JH 1859. "On consulting the Faithful in Matters of Doctrine". http://www.fordham.edu/halsall/mod/newman-faithful.asp

Prior, LA 2013. The Development of Clericalism and the Need for a Theology of Secularity. In Tradition: Fixed and Mobile: Essays in Honour of Rev Prof Rodney Moss. (Ed.) Itumeleng D Mothoagae \& Laurence Prior. Pretoria: Research Institute for Theology and Religion.

Punt, J 2005. "Paul, Body Theology, and Morality: Parameters for a Discussion. Neotestamentica, 39(2):359-388.

Southern African Catholic Bishops' Conference 2013: God, Love, Life and Sex: Guide and Resource for Christian Living Marriage and Family. Pretoria, Gauteng: Southern African Catholic Bishops' Conference.

Swart, I 2013. Revival of a Kairos Consciousness: Prolegomena to a Research Focus on Religious and Social Change in Post-apartheid South Africa. Studia Historiae Ecclesiasticae, vol. 39, no. 2:85-111. 